\title{
Uji Komparasi antara Kegiatan Menulis Angka dan Membuat Kalender dalam Pengenalan Konsep Angka di Kelompok B TK Dharma Wanita Kendal, Jawa Tengah.
}

\author{
Risky Setiawan ${ }^{1}$ Pristi Nur Khamah ${ }^{2}$ \\ Dr. PG-PAUD IKIP Veteran Semarang ${ }^{1}$ Guru TK Dharma Wanita Kendal ${ }^{2}$ \\ setiawan.risky@gmail.com ${ }^{1}$ pristy_nurkhamah@yahoo.co.id ${ }^{2}$
}

Tujuan penelitian ini adalah : 1) Untuk mengetahui apakah ada perbedaan antara kegiatan menulis angka dan kegiatan membuat kalender dalam pengenalan konsep angka pada anak kelompok B TK Dharma Wanita Trisobo, 2) Untuk mengetahui kegiatan manakah yang lebih efektif dalam pengenalan konsep angka di kelompok B TK Dharma Wanita. Subyek penelitian adalah anak didik kelompok B TK Dharma Wanita Trisobo Kecamatan Boja Kabupaten Kendal yang berjumlah 24 anak, 9 anak laki-laki dan 15 anak perempuan. Teknik pengumpulan data yang digunakan ada tiga, yaitu wawancara, observasi dan dokumentasi. Wawancara digunakan sebagai teknik pengumplan data apabila peneliti ingin melakukan studi pendahuluan untuk menemukan permasalahan yang akan diteliti. Observasi digunakan untuk memperoleh data di lapangan, baik yang berkaitan dengan kegiatan yang dilakukan oleh anak maupun guru ketika proses penelitian berlangsung. Sedangkan dokumentasi merupakan data tambahan yang diperoleh dari hasil lembar observasi yang didokumentasikan dalam bentuk gambar ataupun tulisan yang berhubungan dengan kegiatan pembelajaran dan kegiatan penelitian. Kesimpulan yang diperoleh adalah : 1) ada perbedaan antara kegiatan menulis angka dan kegiatan membuat kalender. Hal ini dibuktikan dari hasil output SPSS sebesar -14.750 (14.750> 0.05 (2.060). 2) kegiatan membuat kalender dalam pengenalan konsep angka lebih efektif dari kegiatan menulis angka. Hal ini dibuktikan dengan hasil rata-rata keseluruhan pengenalan konsep angka melalui kegiatan membuat kalender lebih tinggi daripada menulis angka, yaitu $(91,54 \%>59,57 \%)$. Selain itu dikuatkan dengan hasil wawancara yang dilakukan terhadap guru kelas, yang menyatak bahwa melalui kegiatan membuat kalender anak didik menjadi lebih aktif dan kreatif. Ini menunjukkan bahwa kegiatan membuat kalender lebih menunjang proses pembelajaran dalam pengenalan konsep angka pada anak usia dini.

Kata Kunci: komparasi, menulis, kalender, konsep angka

The purpose of this study are: 1) To know whether there is a difference between the activities of writing numbers and activities to create calendars in the introduction of the concept of numbers in the children group B TK Dharma Wanita Trisobo, 2) To know which activities are more effective in the introduction of the concept of numbers in group B TK Dharma Wanita. The subjects of the study were students of group B TK Dharma Wanita Trisobo Boja Subdistrict Kendal District, 24 children, 9 boys and 15 girls. Data collection techniques used there are three, namely interviews, observation and documentation. Interviews are used as data gathering techniques if the researcher wants to do a preliminary study to find the problem to be studied. Observation is used to obtain data in the field, both related to activities undertaken by children and teachers when the research process takes place. While the documentation is additional data obtained from the observation sheet documented in the form of pictures or writings related to learning activities and research activities. The conclusions obtained are: 1) there is a difference between the activities of writing numbers and calendar making activities. This is evidenced by the SPSS output of $-14,750$ (14,750> 0.05 (2.060) 2) the activity of making the calendar in recognition of the concept of numbers is more effective than the activity of writing numbers. This is evidenced by the average results of the overall introduction of the concept of numbers through activities to make the calendar is higher than writing the numbers, ie $(91.54 \%>59.57 \%)$. Also strengthened by the results of interviews conducted on classroom teachers, who insisted that through activities to make the calendar of students become more active and creative. This shows that the activity of making the calendar more support the learning process in recognition of the concept of numbers in early childhood. Keywords: comparisons, writing, calendars, concept numbers 


\section{PENDAHULUAN}

Kontroversi tentang pembelajaran matematika untuk anak usia dini atau yang lebih dikenal dengan calistung di lembaga pendidikan anak usia dini telah menjadi isu yang hangat. Pemberitaan Harian Pikiran Rakyat tanggal 9 Maret 2007 halaman 25, memuat pernyataan Direktur Jenderal Pendidikan Luar Sekolah (PLS) Departeman Pendidikan Nasional, Ace Suyadi, dengan judul "Calistung pada PAUD Salah Besar". Seperti yang dikutip Sriningsih (2008: 2-3), dalam pemberitaan ini disebutkan bahwa:

"Pembelajaran membaca, menulis, dan berhitung (calistung) pada anak usia dini merupakan salah satu bentuk kesalahan terbesar yang diterapkan sistem pendidikan nasional Indonesia. Pada usia dini, pengajaran calistung justru akan membatasi interaksi siswa dengan lingkungan. Meskipun begitu, jika keinginan belajar calistung datang dari diri anak secara langsung, hal itu sah-sah saja."

Kebijakan larangan pengajaran membaca, menulis, dan berhitung di lembaga pendidikan anak usia dini pernah pula dikeluarkan oleh Departemen Pendidikan Nasional pada tahun 1999 sebagaimana dirilis Tempo edisi 12 Desember 1999. Nampaknya, hal ini dilakukan dengan pertimbangan banyaknya kesalahan terhadap praktik pembelajaran calistung di lapangan. Tuntutan agar anak dapat segera menguasai keterampilan akademik terus meningkat. Oleh karena itu, pada pahun 2001 Departemen Pendidikan Nasional menerbitkan pedoman pelaksanaan calistung di lembaga pendidikan anak usia dini. Namun kini, praktik-praktik pembelajaran matematika di lembaga pendidikan anak usia dini, seolah lupa pada amanat-amanat yang tertuang dalam berbagai dokumen yang pernah diterbitkan oleh pemerintah. (Sriningsih, 2008: 3)

Anak usia 4-6 tahun sudah mempunyai kemampuan kognitif yang semakin baik. Begitu anak mampu mengenal angka dengan baik maka akan segera diikuti proses belajar anak dengan cara berhitung. Anak akan mencoba apa saja yang ia saksikan. Saat demikian kemampuan kognitif anak akan berkembang pesat dan keinginan anak untuk belajar semakin tinggi. Pada usia ini anak peka terhadap aspek perkembangan kognitif dan sensitif dalam menerima berbagai upaya pengembangan seluruh potensinya. Perlu dipahami bahwa potensi tersebut hanya dapat berkembang secara optimal jika diberi rangsangan, bimbingan, bantuan, dan perlakuan yang sesuai dengan tingkat pertumbuhan dan perkembangannya.

Salah satu aspek pengembangan kognitif ini adalah pengembangan pembelajaran matematika. Pembelajaran matematika permulaan ini perlu diberikan kepada anak usia dini, karena hampir setiap hari anak sudah terbiasa dengan kegiatan matematika. Anak belajar matematika saat melihat jam dinding, jumlah gambar yang ada di baju mereka, berapa permen yang ia miliki, angka berapa yang dipasang pada kue ulang tahunnya, dan lain sebagainya. Kegiatan pengembangan pembelajaran matematika untuk anak usia dini dirancang agar anak mampu menguasai berbagai pengetahuan dan keterampilan metematika yang memungkinkan mereka untuk hidup dan bekerja pada abad mendatang yang menekankan pada kemampuan memecahkan masalah.

Setelah observasi awal di TK Dharma Wanita Trisobo Kecamatan Boja dilaksanakan, ditemukan beberapa masalah. Permasalahan tersebut antara lain persepsi guru dalam kegiatan pembelajaran masih menyimpang, anak dikatakan belum belajar jika belum belajar menulis, membaca, dan berhitung. Penilaian kemampuan anak dilihat dari hasil akhirnya saja. Motivasi belajar anak terhadap mata pelajaran matematika masih rendah, karena anak menganggap bahwa matematika adalah pelajaran yang susah. Anak sudah bisa menyebutkan urutan bilangan 1-10 bahkan sampai 20, tetapi apabila ditanya angkanya sebagian besar mereka tidak paham dan masih belum bisa menunjukkan angka-angka yang telah disebutkannya. Dari 24 anak hanya 2 anak yang ada dalam kategori sangat baik, 8 anak dalam kategori baik, dan 14 anak dalam kategori tidak baik. Hal ini terjadi karena anakanak menyebutkan bilangan tersebut tanpa melihat bagaimana bentuk angkanya. Guru juga mengalami kesulitan dalam menyelenggarakan kegiatan pembelajaran yang kreatif dan menarik untuk 
anak. Metode yang digunakan oleh pendidik dalam mengenalkan konsep angka kepada anak juga kurang bervariasi, guru sering menggunakan lembar kerja. Kegiatan ini hanya seputar menuliskan angka dan menebalkan tulisan angka, sehingga anak kurang tertarik dengan apa yang disampaikan oleh guru. Hal ini akan mempengaruhi tingkat kemampuan anak terhadap pengenalan konsep angka. Bila masalah ini tidak segera mendapatkan solusi, maka hasil belajar anak tidak sesuai dengan harapan guru dan orang tua.

\section{KAJIAN TEORI}

\section{Kecerdasan Logika Matematika}

Istilah kecerdasan logika matematis (math-logical intelligence) merujuk pada pemahaman paling populer dalam soal logika. Hal tersebut menunjukkan sebuah proses mental berkaitan dengan kemampuan untuk mengatasi masalah yang berhubungan dengan logika. Ada beberapa pendapat tentang definisi kecerdasan ini. Udin (2012) menjelaskan bahwa kecerdasan logis-matematis adalah kemampuan berpikir dalam penalaran atau menghitung, seperti kemampuan menelaah masalah secara logis, ilmiah, dan matematis. Sedangkan menurut Sujiono (2004), kecerdasan logis matematis adalah kecerdasan dalam hal angka dan logika. Kecerdasan ini melibatkan keterampilan mengolah angka dan kemahiran menggunakan angka dan logika. Dari kedua pendapat di atas, dapat disimpulkan bahwa kecerdasan logika matematika adalah kemampuan berpikir dalam hal angka dan logika.

Kusmayadi (2010: 10) menjelaskan bahwa kecerdasan logika metematika ialah kemampuan seseorang dalam memecahkan masalah. Anak dengan kecerdasan logika matematika ini memiliki ciri sebagai berikut: (1) memiliki kemampuan untuk memahami angka dan konsep logika yang sangat bagus. (Sujiono, 2004), (2) senang dan pandai berhitung dan bermain angka. (Udin, 2012), (3) mampu memikirkan dan menyusun solusi (jalan keluar) dengan urutan yang logis (masuk akal), menyukai angka, urutan, logika, dan keteraturan. (Kusmayadi, 2010: 10). Menurut pendapat Gordon dan Cooper (2013: 40) bahwa kecerdasan angka atau kecerdasan numerik adalah kemampuan untuk menggunakan angka-angka dengan baik dan benar. Aritmatika adalah dasar kecerdasan angka, tetapi aspek kecerdasan angka yang lain juga penting, seperti kemampuan bernalar dan memecahkan masalah. Mempelajari matematika membutuhkan begitu banyak hafalan, hitungan atau melacak angka-angka. Keterampilan yang dibutuhkan anak untuk memahami matematika adalah kemampuan untuk mengidentifikasi konsep-konsep matematika yang dapat dipelajari anak melalui kegiatan bermain. Berbagai keterampilan yang dibutuhkan anak dalam memahami konsep matematika antara lain:

1) Patterning (menyusun Pola atau Gambar) adalah menyusun rangkaian warna, bagian-bagian, benda-benda, suara-suara, dan gerakan-gerakan yang dapat diulang. Keterampilan ini sangat penting untuk memperluas pengetahuan anak tentang persamaan dan perbedaan. (Sujiono, 2004). 2) Classification (pengelompokan) adalah salah satu proses penting untuk mengembangkan konsep bilangan, supaya anak mampu menggolongkan atau menyortir benda-benda, mereka harus mengembangkan pengertian tentang "saling memilki", "kesamaan", "keserupaan", "kesamaan", dan "perbedaan". (Susan Sperry S, 2006: 43). 3) Comparing (membandingkan) adalah proses dimana anak membangun suatu hubungan antara dua benda berdasarkan atribut tertentu. Anak usia dini sering membuat perbedaan, terutama bila perbandingan itu melibatkan mereka secara pribadi. (Triharso, 2013: 49). Mulainya Konsep Angka melibatkan pemikiran tentang "berapa jumlahnya atau berapa banyak" termasuk menghitung, menjumlahkan satu tambah satu. 4) Menghitung merupakan cara belajar mengenai nama angka, kemudian menggunakan angka tersebut untuk mengidentifikasi jumlah benda. (Sujiono, 2011). 5) Matching ( mencocokkan) adalah kegiatan hubungan satu-satu yang bertujuan untuk menanamkan konsep pada anak bahwa satu benda dapat dihubungkan dengan benda lain. (Susan, 2006: 36). 


\section{Permainan Matematika Permulaan}

Menurut Slamet Suyanto (2005: 68), konsep bilangan dapat dikenalkan pada anak melalui cara-cara sebagai berikut: (1) Menghitung dengan Jari, hampir semua orang berlatih menghitung permulaan dengan jari tangannya. Guru dapat memulai dengan bertanya misalnya "Berapa banyak jari tangan kita ya?", "Apakah jari tangan kanan sama banyak dengan jari tangan kiri?", atau "Siapa bisa berhitung?". (2) Bermain Domino, kartu domino berisi lingkaran yang mempresentasikan bilangan dari kosong sampai 12. Kartu tersebut baik untuk melatih anak menghitung dan mengenal pola. (3) Menghitung Benda-benda, orang tua dan guru dapat melatih dan menghitung benda apa saja dan dimana saja. Seperti pada penelitian Setiawan (2016) yang mengukur kreativitas guru yang diargumenkan bahwa guru yang kreatif akan dapat membuat anak menjadi kreatif dalam kemampuan matematika permulaannya.

\section{METODE}

Jenis penelitian yang digunakan oleh peneliti yaitu penelitian kuantitatif karena untuk mengolah data dan analisis data diperlukan penyajian data yang berupa angka hasil dari perhitungan dengan cara membandingkan antara variabel yang satu dengan variabel yang lain sehingga diperoleh gambaran tentang keadaan secara jelas dan pasti. Penelitian yang dilakukan adalah penelitian pendidikan, adapun penelitian ini dilakukan di TK Dharma Wanita Trisobo Kecamatan Boja Kabupaten Kendal pada semester II Tahun 2017. Subyek dalam penelitian ini adalah anak didik kelompok B TK Dharma Wanita Trisobo Kecamatan Boja Kabupaten Kendal yang berjumlah 24 anak, 9 anak laki-laki dan 15 anak perempuan. Variabel Dependen

Variabel dependen merupakan variabel yang menjadi pusat perhatian peneliti. Variabel dependen adalah variabel yang nilainya tergantung pada variabel lain, dimana nilainya akan berubah jika variabel yang mempengaruhinya berubah. Variabel dependen dalam penelitian ini adalah Kemampuan Pengenalan Konsep Angka (Y). Variabel independen adalah variabel yang mempengaruhi variabel dependen, baik yang pengaruhnya positif maupun negatif. Variabel independen dalam penelitian ini adalah kegiatan membuat kalender (X). Reliabilitas instrumen menggunakan teknik kappa (antar rater) diperoleh hasil interkorelasi rxx' sebesar 0,99. Dengan demikian, reliabilitas rata-rata rating dari ketiga orang rater tersebut adalah sebesar 0,99 atau lebih dari 0,65, maka disimpulkan indeks keandalan rata-rata adalah konsisten. Kemudian hasil penghitungan estimasi rata-rata reliabilitas bagi seorang rater adalah sebesar 0,98. Maka dapat disimpulkan bahwa konsistensi seorang rater termasuk baik. Uji normalitas data untuk kegiatan menulis angka adalah 0,475 yang nilainya lebih besar dari 0,05 . Sedangkan nilai sig kegiatan membuat kalender adalah 0,97 lebih besar dari 0,05. Dapat disimpulkan bahwa data kegiatan menulis angka dan membuat kalender berdistribusi normal, sehingga data tersebut baik dan layak untuk digunakan dalam penelitian.

\section{HASIL PENELITIAN}

\section{Deskripsi Objek Penelitian}

Deskripsi obyek penelitian berdasarkan pada sampel yang berpasangan (paired), yaitu sampel dengan subyek yang sama namun mengalami dua perlakuan atau pengukuran yang berbeda. Subyek dalam penelitian ini adalah anak didik kelompok B TK Dharma Wanita Trisobo Kecamatan Boja Kabupaten Kendal. Subyek penelitian berjumlah 24 anak, 9 anak laki-laki dan 15 anak perempuan. Perlakuan pertama pada subyek adalah kegiatan menulis angka dan yang kedua adalah kegiatan membuat kalender.

Berikut ini akan diuraikan hasil observasi yang dilakukan pada subyek penelitian. Hasil observasi dari kegiatan menulis angka dan membuat kalender mendapatkan skor yang bervariasi. Hasil skor akan dihitung dengan menggunakan program SPSS 23.0. Penghitungan skor dengan Uji t. Berdasarkan data 
deskriptif statistik, penghitungan dari kegiatan menulis angka dengan bantuan SPSS 23.0 mendapatkan hasil sebagai berikut:

Tabel 1. Hasil Statistik Kegiatan Menulis Angka

One-Sample Statistics

\begin{tabular}{lllll}
\hline & $\mathrm{N}$ & Mean & Std. Deviation & Std. Error Mean \\
\hline menulis angka & 24 & 38.1250 & 9.03285 & 1.84382
\end{tabular}

Output tersebut menunjukkan bahwa dari penghitungan One-Sample Statistics dengan jumlah subyek 24 diperoleh hasil dengan analisis mean (rata-rata) 38,1250 dengan standar deviasi 9,02385.

Tabel 2. Hasil Statistik Kegiatan Menulis Angka

One-Sample Test



Dari tabel di atas diperoleh hasil nilai t hitung dari kegiatan menulis angka sebesar 20,677 dengan derajad kebebasan (df) n-1yaitu 23 dan signifikansi 0,000. Sedangkan penghitungan statistik dari kegiatan menulis angka dengan bantuan SPSS 16.0 mendapatkan hasil sebagai berikut:

Tabel 3. Hasil Statistik Kegiatan Menulis Angka

One-Sample Statistics

\begin{tabular}{lllll}
\hline & $\mathrm{N}$ & Mean & Std. Deviation & Std. Error Mean \\
\hline menulis angka & 24 & 38.1250 & 9.03285 & 1.84382
\end{tabular}

Output tersebut menunjukkan bahwa dari penghitungan One-Sample Statistics dengan jumlah subyek 24 diperoleh hasil dengan analisis mean (rata-rata) 38,1250 dengan standar deviasi 9,02385.

Tabel 4. Hasil Statistik Kegiatan Menulis Angka

One-Sample Test

\begin{tabular}{|c|c|c|c|c|c|c|}
\hline & \multicolumn{6}{|c|}{ Test Value $=0$} \\
\hline & \multirow[b]{2}{*}{$\mathrm{t}$} & \multirow[b]{2}{*}{ df } & \multirow[b]{2}{*}{ Sig. (2-tailed) } & \multirow[b]{2}{*}{ Mean Difference } & $\begin{array}{l}95 \% \\
\text { Differe }\end{array}$ & lence Interval of the \\
\hline & & & & & Lower & Upper \\
\hline menulis angka & 20.677 & 23 & .000 & 38.12500 & 34.310 & 41.9392 \\
\hline
\end{tabular}

Dari tabel di atas diperoleh hasil nilai t hitung dari kegiatan menulis angka sebesar 20,677 dengan derajad kebebasan (df) n-1yaitu 23 dan signifikansi

0,000. Hasil dari observasi kegiatan membuat kalender juga mendapatkan hasil yang bervariasi. Seperti pada kegiatan menulis angka, kegiatan membuat kalender juga akan dilakukan penghitungan statistik. Adapun hasilnya dapat dilihat pada tabel $4.4 \mathrm{a}$ dan $4.4 \mathrm{~b}$ berikut: 
Tabel 5. Hasil Statistik Kegiatan Membuat Kalender

One-Sample Statistics

\begin{tabular}{lllll}
\hline & $\mathrm{N}$ & Mean & Std. Deviation & Std. Error Mean \\
\hline membuat kalender & 24 & 58.5833 & 6.63270 & 1.35389
\end{tabular}

Otput tersebut menunjukkan bahwa dari penghitungan One-Sample Statistics dengan jumlah subjek 24 diperoleh hasil dengan analisis mean (rata-rata) 58,5833 dengan standar deviasi 6,63270.

Tabel 6. Hasil Statistik Kegiatan Membuat Kalender ne-Sample Test

\begin{tabular}{|c|c|c|c|c|c|c|}
\hline & \multicolumn{6}{|c|}{ Test Value $=0$} \\
\hline & \multirow[b]{2}{*}{$\mathrm{t}$} & \multirow[b]{2}{*}{ Df } & \multirow[b]{2}{*}{ Sig. (2-tailed) } & \multirow[b]{2}{*}{ Mean Difference } & \multicolumn{2}{|c|}{$\begin{array}{l}95 \% \text { Confidence Interval of the } \\
\text { Difference }\end{array}$} \\
\hline & & & & & Lower & Upper \\
\hline embuat kalender & 3.270 & 3 & 00 & 3.58333 & 5.7826 & 1.3841 \\
\hline
\end{tabular}

Dari tabel di atas diperoleh hasil nilai t hitung dari kegiatan menulis angka sebesar 43,270 dengan derajad kebebasan (df) n-1yaitu 23 dan signifikansi 0,000. Hasil pengenalan konsep angka di kelompok B TK Dharma Wanita Trisobo tahun 2017 mengalami perbedaan. Nilai rata-rata dari kegiatan membuat kalender lebih besar daripada nilai rata-rata menulis angka. Perbedaan dari kedua hasil statistik antara kegiatan menulis angka dan membuat kalender tersebut dapat dilihat pada tabel 7 berikut.

Tabel 7. Hasil Statistik antara Kegiatan Menulis Angka dan Membuat Kalender

\begin{tabular}{llllll} 
No. & Kegiatan & Mean & T & Std. deviasi & Sig. (2-tailed) \\
\hline 1 & Menulis angka & 38.1250 & 20.677 & 9.03285 & 0.000 \\
\hline 2 & $\begin{array}{l}\text { Membuat } \\
\text { kalender }\end{array}$ & 58.58333 & 43.270 & 6.63270 & 0.000
\end{tabular}

Dari perbandingan hasil statistik di atas dapat diketahui bahwa melalui kegiatan membuat kalender, rata-rata pengenalan konsep angka di kelompok B TK Dharma Wanita Trisobo tahun 2017 lebih besar daripada kegiatan menulis angka.

\section{Hasil Analisis Uji Statistik}

Dari penghitungan statistik yaitu uji $\mathrm{T}$ untuk dua sampel yang berpasangan atau Paired Samples $T$ test, diperoleh hasil sebagai berikut:

Tabel 8. Paired Samples Statistics

\begin{tabular}{llllll}
\hline & Mean & N & Std. Deviation & Std. Error Mean \\
\hline Pair 1 & menulis angka & 38.1250 & 24 & 9.03285 & 1.84382 \\
\cline { 2 - 6 } & membuat kalender & 58.5833 & 24 & 6.63270 & 1.35389
\end{tabular}

Output ini menjelaskan tentang statistik data dari observee. Untuk data "kegiatan menulis angka" nilai rata-rata kemampuan pengenalan konsep angka adalah 38.1250; dari jumlah data 24 standar deviasi 9.03285 dan standar error mean 1.84382. Sedangkan untuk data kegiatan "membuat kalender" 
nilai rata-rata kemampuan pengenalan konsep angka adalah 58.5833; dari jumlah data 24; standar deviasi 6.63270; dan standar error mean 1.35389.

Tabel 9. Paired Samples Correlations

\begin{tabular}{lllll}
\hline & & $\mathrm{N}$ & Correlation & Sig. \\
\hline Pair 1 & menulis angka \& membuat kalender & 24 & .663 & .000
\end{tabular}

Output ini menjelaskan tentang korelasi atau besar hubungan antara variabel "kegiatan menulis angka dan kegiatan membuat kalender". Dari output ini didapat nilai korelasi sebesar 0.663 dengan signifikansi 0,000 . Ini berarti terdapat perbedaan yang sangat kuat antara kegiatan menulis angka dan kegiatan membuat kalender karena nilai yang mendekati 1.

Tabel 10. Paired Samples Test

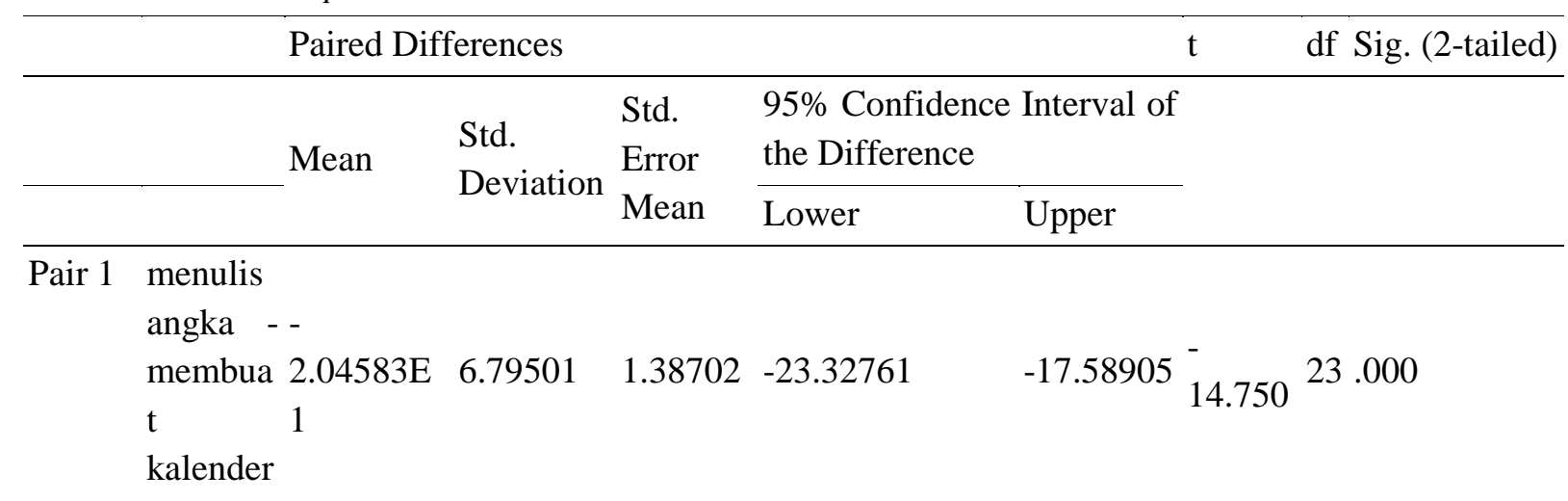

Output ini menjelaskan tentang hasil uji t sampel berpasangan. Pengujian menggunakan tingkat signifikansi 0,05 ( secara default SPSS sudah menggunakan tingkat signifikansi 0,05) dan uji 2 sisi.

Hasil pengujian hasil $t$ hitung nilai $t$ hitung adalah -14.750 . Harga $t$ tabel dapat dilihat pada tabel statistik pada signifikansi $0,05: 2=0,025$ (uji 2 sisi) dengan derajat kebebasan (df) $n-1$ atau 24-1 =23, hasil diperoleh untuk $\mathrm{t}$ tabel sebesar 2,069/-2,069 ( lihat pada lampiran tabel $\mathrm{t}$ ). Nilai -t hitung $<-\mathrm{t}$ tabel $(-14,750<-2,069)$ maka Ho ditolak. Jadi dapat disimpulkan bahwa terdapat perbedaan antara kegiatan menulis angka dan kegiatan membuat kalender dalam pengenalan konsep angka di kelompok B TK Dharma Wanita tahun 2017. Dari rata-rata (mean) dapat diketahui rata-rata kegiatan membuat kalender lebih tinggi daripada sebelumnya. Hal ini dapat diartikan bahwa kegiatan membuat kalender terbukti efektif dalam pengenalan konsep angka di kelompok B TK Dharma Wanita Trisobo tahun 2017. Pengambilan keputusan berdasar signifikansi

Berdasar signifikansi, jika signifikansi $<0,05$ maka Ho ditolak, dan jika signifikansi $>0,05$ maka Ho diterima. Karena signifikansi $(0,000<0,05)$ maka Ho ditolak. Artinya terdapat perbedaan antara kegiatan menulis angka dan kegiatan membuat kalender dalam pengenalan konsep angka di kelompok B TK Dharma Wanita tahun 2017. Menentukan daerah kritis Berdasarkan output SPSS diperoleh hasil thitung -14.750, maka dapat digambarkan melalui kurva normal berikut ini.

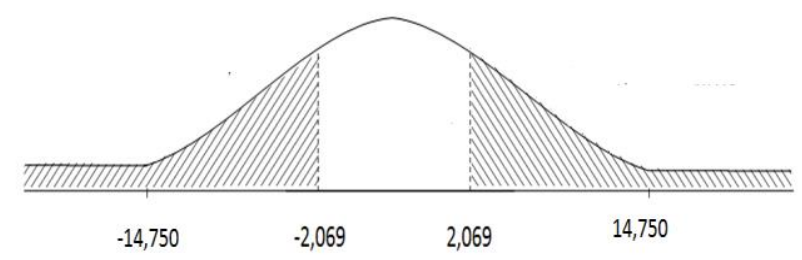

Gambar 1. Grafik Kurva Normal 
Dari hasil penghitungan data dan yang ditunjukkan pada gambar di atas, maka hasil t hitung jatuh pada daerah penolakan Ho, maka dapat dinyatakan bahwa hipotesis nol yang menyatakan tidak ada perbedaan antara kegiatan menulis angka dan membuat kelender dalam pengenalan konsep angka di kelompok B TK Dharma Wanita Trisobo tahun 2017 ditolak, dan hipotesis alternatif diterima. Jadi kesimpulannya terdapat perbedaan antara kegiatan menulis angka dan kegiatann membuat kalender dalam pengenalan konsep angka di kelompok B TK Dharma Wanita tahun 2017.

\section{DISKUSI}

Berdasarkan pada penghitungan statistik menunjukkan bahwa hasil dari penelitian di kelompok B TK Dharma Wanita Trisobo mengalami perbedaan. Treatment atau perlakuan pada subyek dalam penelitian ini adalah kegiatan menulis angka dan membuat kalender, yang mengacu pada pengenalan konsep angka 1-20. Kegiatan membuat kalender memberikan peran yang cukup besar untuk menunjang keberhasilan dalam proses belajar mengajar, khususnya pada pembelajaran pengenalan konsep angka pada anak. Dari observasi yang telah dilakukan, diperoleh hasil yang berbeda. Jika dibandingkan, jumlah skor dari hasil observasi pada kegiatan membuat kalender lebih baik bahkan lebih tinggi daripada kegiatan menulis angka. Perbandingan menurut hasil uji statistik untuk dua sampel yang berpasangan atau paired samples $T$ test dapat dilihat pada tabel di bawah ini:

Tabel 11. Perbandingan Hasil Uji T

\begin{tabular}{|c|c|c|c|c|}
\hline \multirow{2}{*}{ No. } & \multirow{2}{*}{ Hasil Analisis } & $\begin{array}{l}\text { Kegiatan } \\
\text { Angka }\end{array}$ & Menulis & \multirow{2}{*}{$\begin{array}{l}\text { Kegiatan Membuat Kalender } \\
\text { Total Nilai }\end{array}$} \\
\hline & & Total Nilai & & \\
\hline 1 & $\overline{\Sigma R}$ & 915 & & 1406 \\
\hline 2 & Mean & 38.1250 & & 58.5833 \\
\hline 3 & Standar Deviasi & 9.03285 & & 6.63270 \\
\hline
\end{tabular}

Sedangkan secara keseluruhan rata-rata dari hasil kegiatan menulis angka dan membuat kalender pada penghitungan statistik di atas dapat dibandingkan seperti pada gambar grafik di bawah ini:



Gambar 2. Grafik Perbandingan Mean dan Standar Deviasi.

Dari penghitungan statistik di atas, baik menggunakan analisis deskriptif kuantitatif maupun uji t untuk dua sampel berpasangan atau Paired Samples $T$ test mendapatkan hasil yang berbeda. Nilai rata-rata pengenalan konsep angka 1-20 melalui kegiatan membuat kalender lebih baik jika dibandingkan dengan kegiatan menulis angka. Hal ini menunjukkan bahwa kegiatan pembelajaran yang diberikan oleh guru dapat mempengaruhi tingkat keberhasilan dalam penyampaian materi kepada anak didik. Karena itulah, desain pembelajaran bagi anak didik merupakan sebuah keharusan sehingga peningkatan kualitas kognitif anak tercapai secara maksimal. 
Hasil penelitian ini semakin mendukung bahwa kegiatan pembelajaran, khususnya di Taman Kanak-Kanak merupakan bentuk pelaksanaan kegiatan yang bertujuan untuk membantu anak didik dalam mengenal, menumbuhkan, dan mengembangkan diri, sikap, dan kebiasaan belajar yang baik untuk menguasai pengetahuan dan keterampilan sesuai program pembelajaran di sekolah. Kegiatan membuat kalender cukup menentukan hasil yang maksimal pada pembelajaran di kelompok B TK Dharma Wanita Trisobo tahun 2017.

Penelitian yang dilakukan oleh Dian Nur Fitriya, program studi PG-PAUD, Fakultas Ilmu Pendidikan, Universitas Negeri Surabaya berjudul Peningkatan Kemampuan Mengenal Bilangan Melalui Permainan Kereta Angka pada Anak Kelompok A TK Dharma Wanita Desa Sumbersono Kabupaten Mojokerto. Penelitian ini bertujuan untuk meningkatkan kemampuan mengenal bilangan melalui permainan kereta angka. Penelitian ini merupakan penelitian tindakan kelas yang terdiri atas 2 siklus. Subyek penelitian adalah anak kelompok A TK Sumbersono yang berjumlah 20 anak. Metode pengumpulan data menggunakan observasi dan dokumentasi, data yang terkumpul dianalisis menggunakan statistik deskriptif. Hasil penelitian siklus I menunjukkan bahwa kemampuan anak dalam mengenal bilangan 1-5 sebesar 66\%. Hasil penelitian pada siklus II meningkat menjadi $80 \%$. Berdasarkan penelitian tersebut dapat disimpulkan bahwa permainan kereta angka dapat meningkatkan kemampuan anak dalam mengenal bilangan 1-5 pada anak kelompok A TK Dharma Wanita Sumbersono. Penelitian tersebut juga dapat mengoptimalkan kemampuan konsep angka melalui permainan yang mengasyikkan. Sehingga jika setiap guru memiliki kreativitas dalam menyajikan setiap materi yang akan disampaikan, maka tidak menutup kemungkinan keberhasilan pembelajaran akan menjadi lebih baik. Dengan demikian, antara kegiatan menulis angka dan membuat kalender dalam pengenalan konsep angka di kelompok B TK Dharma Wanita Trisobo tahun 2017 menunjukkan hasil yang berbeda. Sesuai dengan hipotesis awal, yaitu:Ho; Tidak ada perbedaan antara kegiatan menulis angka dan membuat kalender dalam pengenalan konsep angka di kelompok B TK Dharma Wanita Trisobo tahun 2017. Ha; Ada perbedaan antara kegiatan menulis angka dan membuat kalender dalam pengenalan konsep angka di kelompok B TK Dharma Wanita Trisobo tahun 2017. Dari analisis uji $\mathrm{t}$ untuk dua sampel berpasangan atau Paired Samples $T$ test telihat bahwa nilai $-\mathrm{t}$ hitung $<-t$ tabel $(-14,750<-2,069)$ maka Ho ditolak. Jadi dapat disimpulkan bahwa terdapat perbedaan antara kegiatan menulis angka dan kegiatan membuat kalender dalam pengenalan konsep angka di kelompok B TK Dharma Wanita tahun 2017. Dari penghitungan data menggunakan analisis deskriptif kuantitatif diperoleh hasil (mean) rata-rata kegiatan membuat kalender secara keseluruhan lebih tinggi daripada sebelumnya, yaitu 91,54\% $>59,57 \%$. Didukung oleh hasil wawancara terhadap guru kelas yang dilakukan setelah kegiatan penelitian. Dari wawancara tersebut guru kelas menyatakan bahwa melalui kegiatan membuat kalender anak didik menjadi lebih aktif dan kreatif. Hal ini dapat diartikan bahwa kegiatan membuat kalender terbukti lebih efektif dalam pengenalan konsep angka di kelompok B TK Dharma Wanita Trisobo tahun 2017.

\section{KESIMPULAN}

Terdapat perbedaan antara kegiatan menulis angka dan kegiatan membuat kalender dalam pengenalan konsep angka pada anak kelompok B TK Dharma Wanita Trisobo, hal ini dibuktikan dari hasil output SPSS nilai -t hitung sebesar -14.750, (-14. 750 < -2.069). Kegiatan pembuatan kalender lebih efektif dalam pengenalan konsep angka di kelompok B TK Dharma Wanita Trisobo tahun 2017, hal ini dilihat dari perbedaan rata- rata (mean) kegiatan membuat kalender lebih besar dari pada menulis angka yaitu $91,54 \%>59,57 \%$.

\section{REFERENSI}

Arikunto, Suharsimi (2010). Prosedur Penelitian: Suatu Pendekatan Praktik. Jakarta: Rineka Cipta

Carter, Philip (2009). Test and Assess Your Brain Quotien. India: Replika Press

Enterprise, Jubilee (2014). SPSS untuk Pemula. Jakarta: Elex Media Komputindo

Gordon, C. \& Cooper, L.H. (2012). Meningkatkan 9 Kecerdasan Anak. Alih Bahasa: Cynthia Rozyandra Jakarta: Bhuana Ilmu Populer 
Jamaris, Martini (2005). Perkembangan dan Pengembangan Anak Usia Taman Kanak-Kanak. Jakarta: Universitas Negeri Jakarta

Kumaidi \& Manfaat B. (2013). Pengantar Metode Statistika: Teori dan Terapannya dalam Penelitian Bidang Pendidikan dan Psikologi. Cirebon: Eduvision Publishing

Kusmayadi, Ismail (2010). Kemahiran Interpersonal untuk Guru. Bandung: Pribumi Mekar.

Nunes, T. \& Bryant, P. (1998). Children Doing Mathematics. Great Britain: Athenaeum Press

Peraturan Menteri Pendidikan dan Kebudayaan Republik Indonesia Nomor 137 Tahun 2014, Tentang Standar Nasional Pendidikan Anak Usia Dini.

Pusat Pembinaan dan Pengembangan Bahasa (1991). Kamus Besar Bahasa Indonesia. Jakarta: Balai Pustaka

Rahmawati, Hanik (2014). Efektivitas Metode Bercerita dengan Penggunaan Program Power Point untuk Meningkatkan Kemampuan Mengenal Konsep Bilangan 1-10 pada Kelompok A di TK PGRI 59 Manyaran. Semarang: Fakultas Ilmu Pendidikan Anak Usia Dini IKIP Veteran Semarang.

Setiawan, R. (2017). The Influence of Income, Experience, and Academic Qualification on the Early Chilhood Education Teachers' Creativity in Semarang, Indonesia. International Journal of Instruction, 10(4), 39-50. https://doi.org/10.12973/iji.2017.1043a

Smith, Susan Sperry (2006). Early Childhood Mathematics. USA: Pearson Education

Sriningsih, Nining (2009). Matematika Terpadu untuk Anak Usia Dini. Bandung: Pustaka Sebelas

Sudaryanti (2006), Pengenalan Matematika Anak Usia Dini. Yogyakarta: Universitas Negeri Yogyakarta Press

Sugiono (2014). Metode Penelitian Kombinasi (Mixed Methods). Bandung: Alfabeta

Sujiono, Yuliani Nurani (2011). Metode Pengembangan Kognitif. Jakarta: Universitas Terbuka

Suriasumantri, Jujun S. (1982). Filsafat Ilmu. Jakarta: Pustaka Sinar Harapan

Suyanto, Slamet (2005), Dasar-Dasar Pendidikan Anak Usia Dni. Yogyakarta: Hiayat

Triharso, Agung (2013). Permainan Kreatif dan Edukatif untuk Anak Usia Dini: 30 Permainan Matematika dan Sains. Yogyakarta: ANDI

Wahyudin (2008). Pembelajaran dan Model-Model Pembelajaran: Pelengkap untuk Meningkatkan Kompetensi Pedagogis Para Guru dan Calon Guru Profesional. Jakarta: IPA Abong

Winataputra, Udin S. (2012). Teori Belajar dan Pembelajaran. Tangerang: Universitas Terbuka 